\title{
Screening of three phenol-degrading bacteria for copper bioremoval of copper
}

\section{Paper received: 06.12.2017 \\ Authors Info \\ S.A.W. Sha'arani, M.Y. Shukor, A.A. Basirun and S.A. Ahmad* Department of Biochemistry, Faculty of Biotechnology and Biomolecular Sciences, Universiti Putra Malaysia, 43400, Selangor, Malaysia}

Revised received: 17.04 .2018

Re-revised received: 01.01.2018
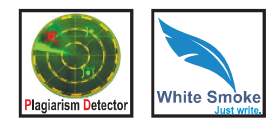

${ }^{*}$ Corresponding Author Email : aqlimaahmad@gmail.com

\section{Edited by \\ Professor Jayashree Rout}

Reviewed by

Dr. N.M. Roli

Dr. R.B. Raizada

\section{Abstract}

Aim : Potential microbial isolates for bioremoval of copper were collected from phenolic and heavy metalcontaminated soils and screened in copper-containing medium for determining the maximum tolerance level for copper.

Methodology : Bioremoval of copper was assessed using sodium diethyl dithiocarbamate assay. Physical and cultural conditions influencing copper bioremoval such as initial concentration, biomass dosage (inoculum volume), temperature and $\mathrm{pH}$ were optimised via one-factor-at-a-time.

Results : The highest maximum tolerance level was displayed by Serratia sp. AQ5-03 at $600 \mathrm{mg} \mathrm{l}^{-1}$, while for Alcaligenes sp.AQ5-02 and Pseudomonas sp. AQ5-04 it was $500 \mathrm{mg} \mathrm{l}^{-1}$. The highest bioremoval for Alcaligenes $\mathrm{sp}$. AQ5-02, Serratia sp. AQ5-03 and Pseudomonas sp. AQ5-04 was achieved at 20, 50 and $75 \mathrm{mg} \mathrm{l}^{-1}$, respectively. The optimum biomass dosage (inoculum volume) for both Serratia sp. AQ5-03 and Pseudomonas sp. AQ5-04 were $15 \%$, whereas it was $10 \%$ for Alcaligenes sp. AQ5-02. The results also revealed that maximum bioremoval was achieved at $\mathrm{pH} 6$ at an optimum temperature of $20^{\circ} \mathrm{C}$ for both Alcaligenes sp. AQ5-02 and Pseudomonas sp. AQ5-04, while Serratia sp. AQ5-03 showed optimum removal at $\mathrm{pH} 7$ and at $30^{\circ} \mathrm{C}$ temperature. The maximum bioremoval efficiency for Alcaligenes sp. AQ502, Serratia sp. AQ5-03 and Pseudomonas sp were found to be 62,57 and $70 \%$, respectively.

Interpretation : The results indicate that Alcaligenes sp. AQ5-02, Serratia sp. AQ5-03, Pseudomonas sp. AQ5-04 can be utilised as

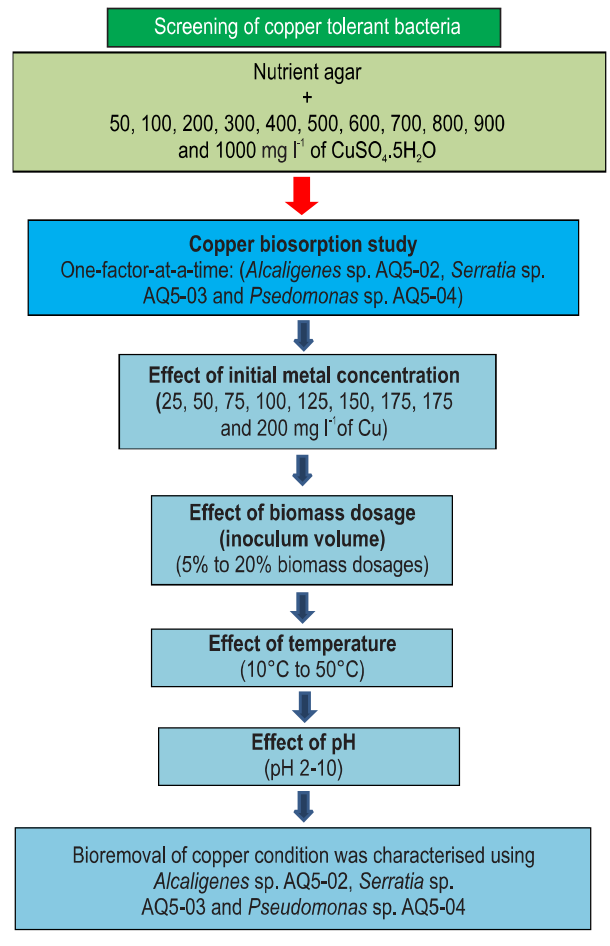
bioremoval agent since it possessed the highest bioremoval efficiency for copper remediation.

Key words: Alcaligenes sp., Bioremoval, Copper, Pseudomonas sp., Serratia sp.

How to cite : Sha'arani, S.A.W., M.Y. Shukor, A.A. Basirun and S.A. Ahmad: Screening of three phenol-degrading bacteria for copper bioremoval of copper. J. Environ. Biol., 40, 1045-1051 (2019). DOI : http://doi.org/10.22438/jeb/40/5/MRN-803 


\section{Introduction}

Heavy metal contamination has become a critical environmental problem throughout the world despite its use in many manufacturing processes, which usually ends up as waste in industrial effluents (Hasayen et al., 2017; Halmi et al., 2016). Accumulation of heavy metals in the waste streams can increase metal toxicity in living organisms the moment they are released into the ecosystem. Among the important metals, mercury, lead, cadmium and chromium are considered as toxic whereas copper, nickel, cobalt, zinc in small amount are not toxic. However, their widespread applications and elevating levels in the environment are of serious concerns (Khayat et al., 2016; Hansda et al., 2015; Waykar and Petare, 2016). Copper is a crucial trace element involved in plant and animal metabolism. It plays an important role in the biosynthesis of proteins, nucleic acids, secondary metabolites, growth substances and gene expression (Duraipandian et al., 2015); however, beyond permissible limit, it shows adverse effects on the environment and humans. High concentrations of copper causes anaemia, liver and kidney damage, stomach and intestinal irritation, central nervous system irritation and Wilson's disease that leads to brain and liver damage (Majumder et al., 2015).

Decontamination of heavy metals from soil and water around industries like has become a challenge for a long period. Various treatment processes chemical precipitation, filtration, ion exchange, electrochemical treatment, membrane technologies and evaporation for removd of copper have been proposed (Rajendran et al., 2003). However, these conventional methods are considered ineffective and uneconomical in reducing copper due to their high capital and operating cost. Alternatively, cost effective and green technologies are in great demand to reduce heavy metals from aqueous solution. Bioremediation is a popular method used to degrade toxic organic pollutants such as heavy metals using bacteria, fungi, algae (Karamba et al., 2016; Ghosh and Saha, 2013; Akinkunmi et al., 2016; Busi et al., 2016; Jaiswar et al., 2015). Metal removal by bacteria is generally achieved through chelation and surface adsorption mechanism. Live or dead microbial cells along with their products are the best bioaccumulators from both soluble and particulate forms of metal. In previous studies, it has been reported that soluble metal ions in the environment can be trapped by microorganisms due to negatively charged groups attached within their cell wall structures (Ölmezoğlu et al., 2012).

In view of the above, the present study focused on the screening and determination of copper maximum tolerance level and copper bioremediation capability using phenol-degrading bacteria along with its characterization. Optimum value of various operating conditions (initial copper (II) concentration, biomass dosage (inoculum volume), $\mathrm{pH}$ and temperature) for copper bioremediation were obtained by conducting batch experimental study via one-factor-at-a-time approach. Although recent studies have shown an increased number of phenol-degrading strains, the novelty of this study might be achieved by investigating the tolerance of phenol-degrading strains towards copper.

\section{Materials and Methods}

Selection of heavy metal tolerant bacterial strains: A total of ten bacterial strains were collected from the Bacterial Collection of Bioremediation Group, Department of Biochemistry, Universiti Putra Malaysia to carry out the copper remediation study. These microbial strains were isolated from various sources of polluted area, including Malaysia and Antarctica. Bacterial strains were aseptically streaked on nutrient agar plates supplemented with $50-1000 \mathrm{mg} \mathrm{l}^{-1}$ of copper sulphate pentahydrate $\left(\mathrm{CuSO}_{4} \cdot 5 \mathrm{H}_{2} \mathrm{O}\right)$. Bacterial growth was observed on each plate after incubation at $30^{\circ} \mathrm{C} \pm 2$ for $48 \mathrm{hr}$. The highest concentration of individual metal supporting bacterial growth was defined as maximum tolerance level.

Preparation of metal solution: $\mathrm{CuSO}_{4}, 5 \mathrm{H}_{2} \mathrm{O}$ was dissolved in distilled water to prepare a stock solution of copper. $\mathrm{A} 1000 \mathrm{mg} \mathrm{I}^{-1}$ $\mathrm{Cu}(\mathrm{II})$ stock solution was prepared by diluting $3.93 \mathrm{~g}$ of $\mathrm{CuSO}_{4}$. $5 \mathrm{H}_{2} \mathrm{O}$ in 1 I of distilled water. Different concentrations $(25,50,75$, $100,125,150,175$ and $200 \mathrm{mg} \mathrm{l}^{-1}$ ) of copper solution were prepared using this stock solution.

Copper biosorption study: Minimal salt media comprising $\mathrm{CaCl}_{2} \cdot 2 \mathrm{H}_{2} \mathrm{O}, \mathrm{KH}_{2} \mathrm{PO}_{4}, \mathrm{NH}_{4} \mathrm{Cl}, \mathrm{MgSO}_{4} \cdot 7 \mathrm{H}_{2} \mathrm{O}, \mathrm{KCl}, \mathrm{NaCl}$ and glucose with different concentration of copper was prepared for the study. Copper added media was autoclaved in universal bottle containing $10 \mathrm{ml}$ minimal salt media. The media was then inoculated at a ratio of $1 \%$ for the isolated bacteria and minimal salt media. The universal bottles were agitated in a shaker incubator at $120 \mathrm{rpm}$ and $30^{\circ} \mathrm{C}$. The samples were taken at predetermined time intervals and centrifuged at $6000 \mathrm{rpm}$ for $10 \mathrm{~min}$ using Beckman Avanti J-20. The supernatant fraction was analysed for the remaining copper ions in the bioremediation media where copper reduction was read spectrophotometrically (Shimadzu U.V. Mini 124) at $460 \mathrm{~nm}$ using sodium diethyl dithiocarbamate as a complexing agent (Aksu et al., 1998). Biosorption percent of copper was obtained.

$$
\text { Copper biosorption }(\%)=\left(C_{0}-C_{1}\right) / C 0 * 100 \%
$$

Where, $\mathrm{C}_{0}$ is the initial $\mathrm{Cu}$ concentration and $\mathrm{C}_{1}$ is the remaining copper concentration. Standard graph was used for calculating the remaining copper concentration obtained from the optical density. Four parameters were studied for bioremoval of copper. Firstly, the effects of initial metal concentrations towards microbial biomass were examined in the metal solution at different concentrations $(25,50,75,100$, $125,150,175$, and $\left.200 \mathrm{mg} \mathrm{l}^{-1}\right)$ at fixed temperature. Biomass dosage was then optimised by varying the number of biomass concentration such as $5 \%, 10 \%, 15 \%$ and $20 \%$ (inoculum volume). Later, the study on determining the optimum temperature was performed at $10,20,27,30,40$ and $50^{\circ} \mathrm{C}$. Lastly, metal removal was monitored in terms of $\mathrm{pH}$ varying 
from 2, 3, 4, 5, 6, 7, 8, 9 and 10 for each isolate. The $\mathrm{pH}$ of media was adjusted using $1 \mathrm{M} \mathrm{HCl}$ and $1 \mathrm{M} \mathrm{NaOH}$.

Statistical analyses: All experiments were carried out in triplicate. Data shown in the corresponding figures are the mean values of the experiment and expressed as mean $\pm S D$, while one wayANOVA was used to examine the differences.

\section{Results and Discussion}

Previous studies have reported that all bacteria have the capacity in remediating contaminants such as phenol and glyphosphate (Manogaran et al., 2017; Lee et al., 2018). Seven bacterial strain were identified as Alcaligenes sp. AQ5-02, Serratia sp. AQ5-03, Pseudomonas sp. AQ5-04, Burkholderia vietnamiensis AQ5-12, Burkholderia sp. AQ5-13, Arthrobacter sp. AQ5-06 and Rhodococcus sp. AQ5-07 (1) for their capacity to degrade specific contaminants including glyphosate and phenol. Meanwhile, the other three bacterial isolates remained unidentified; however, it was noticed that they also had the potential to degrade other contaminants other then $\mathrm{Cu}$. All bacteria were used to screen high tolerance to $\mathrm{Cu}$ at varying concentrations. Nutrient agar supplemented with different concentration of $\mathrm{Cu}$ was prepared to screen all bacteria with the ability to tolerate $\mathrm{Cu}$. This is an important step in screening $\mathrm{Cu}$ tolerant bacteria. Table 1 displays the effect of different $\mathrm{Cu}$ concentration on bacterial growth of bacterial isolates.

These bacterial strains showed various tolerance levels when grown in nutrient medium amended with varying concentration of $\mathrm{Cu}$. Most bacteria were found to grow on medium containing $50 \mathrm{mgl}^{-1} \mathrm{Cu}$, except bacterial sample 9 and 10 . These microbial strains were actually isolated from Antarctica; thus, they might require longer incubation period to grow compared to the local bacterial strains. Besides, incubation at $30^{\circ} \mathrm{C}$ did not suit their niche of adapting at very low temperature (Bajerski et al., 2017). An increase in Cu concentration to $1000 \mathrm{mg} \mathrm{l}^{-1}$ exhibited less growth among the bacterias. In fact, more strain was to able to grow to such concentration. It is vital for bacteria to certify that metal uptake and availability is in accordance with the physiological needs, as an imbalance in bacterial metal homeostasis is deleterious (Porcheron et al., 2013). Though, Cu is an essential nutrient requested for general biochemical and physiological functions, excessive exposure to Cu could lead to toxicity (Tchounwou et al., 2012). Maximum tolerance level was best performed by bacterial sample 2 at $600 \mathrm{mg} \mathrm{l}^{-1}$ of Cu followed by bacterial sample 1 and 3 with their maximum tolerance level recorded at $500 \mathrm{mgl}^{-1}$ of $\mathrm{Cu}$.

All three bacteria (bacterial sample 1, 2 and 3) were identified and resided at GenBank NCBI as Alcaligenes sp. AQ5-02, Serratia sp. strain AQ5-03 and Pseudomonas sp. strain AQ5-04, respectively. Nageswaran et al. (2012) tested eight isolated strains of Serratia marcescens to screen $\mathrm{Cu}$ resistance of using similar methodology. It was reported that the isolates whose growth was visible even at $100 \mu \mathrm{g} \mathrm{ml}^{-1}$, were further grown at higher metal concentration of $200 \mu \mathrm{g} \mathrm{ml}^{-1}, 400 \mu \mathrm{g}$ $\mathrm{ml}^{-1}$ and $800 \mu \mathrm{g} \mathrm{ml}^{-1}$, respectively, from a $1000 \mathrm{\mu g} \mathrm{ml}^{-1}$ metal stock solution. Meanwhile, Pseudomonas species is a well-known biosorbent for $\mathrm{Cu}$ remediation for decades (Alireza, 2012). Therefore, Alcaligenes sp. AQ5-02, Serratia sp. strain AQ5-03 and Pseudomonas sp. strainAQ5-04 were selected for further study.

The effects of initial concentration on metal removal by biomass of selected strains were evaluated and is shown in Fig. 1 (a). The maximum bioremoval of metal was recovered at a low initial metal ion concentration; $41 \%$ for Alcaligenes sp. AQ5-02 at $25 \mathrm{mg} \mathrm{l}^{-1}, 39 \%$ for Serratia sp. AQ5-03 at $50 \mathrm{mg} \mathrm{l}^{-1}$ and $43 \%$ at 75 $\mathrm{mg} \mathrm{l}^{-1}$ for Pseudomonas sp. AQ5-04. The decrease in bioremoval percentage may be attributed to inadequate free sites for metal bioremoval. Nonetheless, at lower concentration, all metal ions present in the solution were able to interact with the binding sites, thus increasing the percentage of bioremoval compared to higher ion concentration as focused in this study. At higher concentration, the adsorption yield was observed to be low due to the saturation of adsorption sites (Shawky et al., 2016, Oves et al., 2013; Pandiyan and Mahendradas, 2011).

The importance of biomass dosage parameter is related to the optimum concentration combined with maximum efficiency in metal removal of copper for each strain. The removal of copper reached up to 49,48 and $60 \%$ for Alcaligenes sp. AQ5-02, Serratia sp. AQ5-03 and Pseudomonas sp. AQ504, respectively (Fig. 1 b). In addition, copper removal was noticed to be steady or decreased with biomass dosage due to the screening effect between cells. This blacked the active sites of the cells by the increment of biomass in the system (Hammaini et al., 2007). Similar trend was also observed in a previous study by Majumder et al. (2015) which suggested that this may be attributed to the high surface area to volume ratio leading to a better metal uptake. Besides, with the increase in biomass dosage, the decrease in bioremoval capacity may be observed due to unsaturated binding sites and reduction in the effective surface area (Hansda et al., 2015)

The effects of temperature on copper bioremoval by biomass of selected strains is shown in Fig. 1 ( ). The optimum bioremoval of copper for Alcaligenes sp. AQ5-02, Serratia sp. AQ5-03 and Pseudomonas sp. AQ5-04 was 56,41 and $49 \%$ at 20 and $20^{\circ} \mathrm{C}$, respectively. The results indicated the optimum temperature for all strains ranging from 20 to $30^{\circ} \mathrm{C}(\mathrm{P}<0.05)$. These results corroborate the previous report of Hansda et al. (2015) who suggested that temperature affects bioremoval process to a lesser extent within the range of 20 to $35^{\circ} \mathrm{C}$. An increase in temperature is responsible for the reduction in bioremoval capacity of the biomass as well as physical damage due to the exothermic nature of some removal processes. In addition, areas with high copper concentration like Lohan river (near Mamut Copper Mine (MCM), Sabah), the daily temperature ranging from 20 to $35^{\circ} \mathrm{C}$ could enhance removal from the polluted site (van der Ent and Edraki, 2016). Fig. 1 (d) shows the effect of $\mathrm{pH}$ value on bioremoval of copper by microbial biomass. 

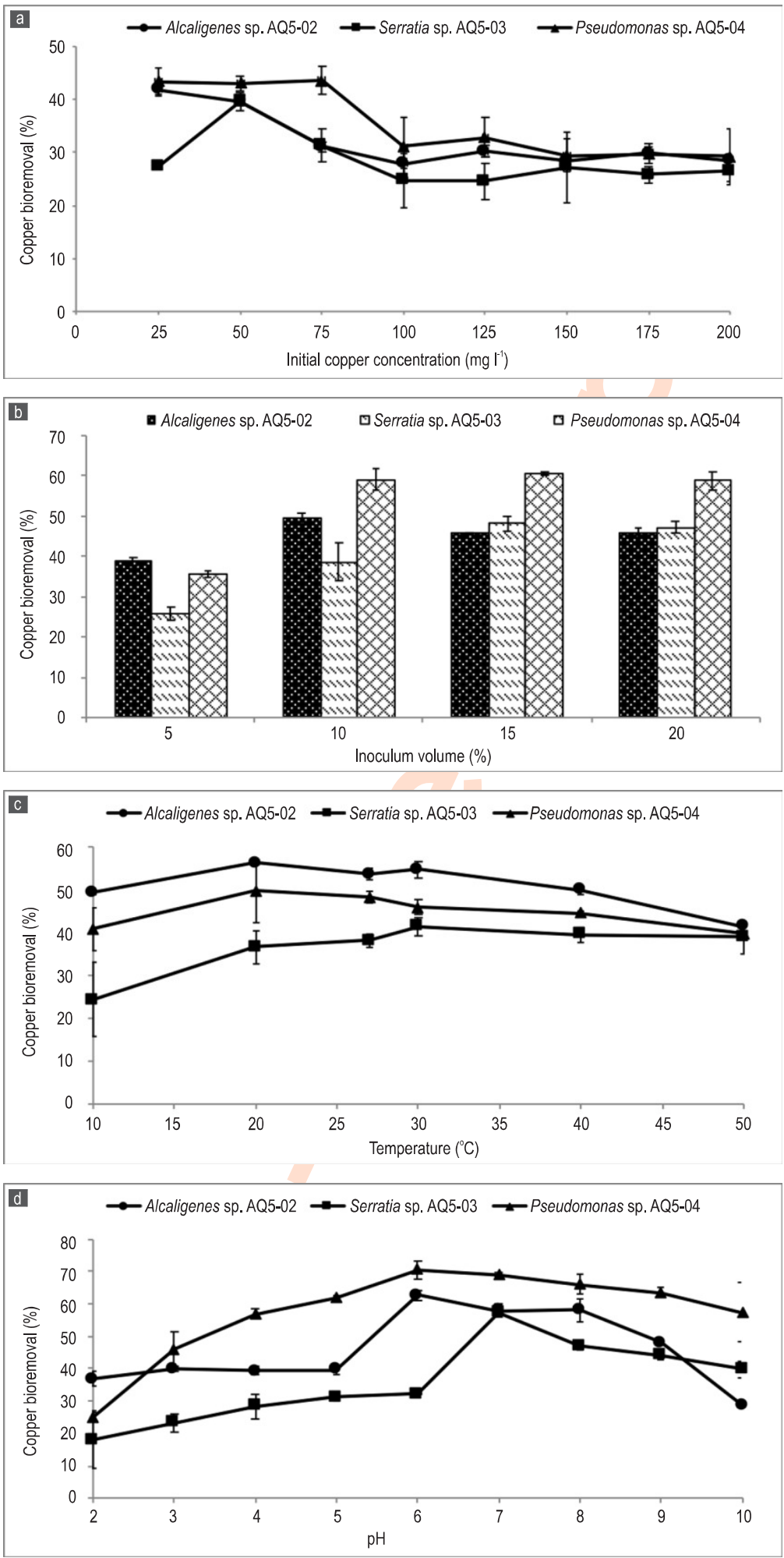

Fig. 1: Effect of (a) initial concentration, (b) biomass dosage (inoculum volume), (c) temperature and (d) pH on copper bioremoval by using living cells of Alcaligenes sp. AQ5-02, Serratia sp. AQ5-03 and Pseudomonas sp. AQ5-04. All values represent mean of three replicates \pm SD. 
Table 1: Maximum tolerance level of copper for various collected strains

\begin{tabular}{|c|c|c|c|c|c|c|c|c|c|c|c|c|}
\hline \multicolumn{5}{|c|}{ Samples } & \multicolumn{7}{|c|}{ Copper concentration ( $\left.\mathrm{mg} \mathrm{l}^{-1}\right)$} & \multirow[b]{2}{*}{1000} \\
\hline No & $\begin{array}{l}\text { Bacteria/ Accession no. } \\
\text { (GenBank, NCBI)/ } \\
\text { Bioremedition }\end{array}$ & 50 & 100 & 200 & 300 & 400 & 500 & 600 & 700 & 800 & 900 & \\
\hline 1 & $\begin{array}{l}\text { Alcaligenes sp. } \\
\text { AQ5-02 } \\
\text { (Kt693286) } \\
\text { Phenol degradation }\end{array}$ & ++++ & ++++ & ++++ & ++++ & +++ & + & - & - & - & - & - \\
\hline 2 & $\begin{array}{l}\text { Serratia sp. } \\
\text { AQ5-03 } \\
\text { (Kt693287) Phenol } \\
\text { degradation }\end{array}$ & ++++ & ++++ & ++++ & ++++ & ++++ & ++++ & ++ & - & - & - & - \\
\hline 3 & $\begin{array}{l}\text { Pseudomonas sp. } \\
\text { AQ5-04 } \\
\text { (Kt693288) } \\
\text { Phenol degradation }\end{array}$ & ++++ & ++++ & ++++ & ++++ & +++ & + & - & - & - & - & - \\
\hline 4 & $\begin{array}{l}\text { Unidentified bacteria } \\
\text { Glyphosate degradation }\end{array}$ & + & - & - & - & - & - & - & - & - & - & - \\
\hline 5 & $\begin{array}{l}\text { Burkholderia } \\
\text { vietnamiensis AQ5-12 } \\
\text { (Kx792233) } \\
\text { Glyphosate degradation }\end{array}$ & ++++ & ++++ & ++++ & - & - & - & - & - & - & - & - \\
\hline 6 & $\begin{array}{l}\text { Burkholderia sp. } \\
\text { AQ5-13 } \\
\text { (Kx792234) } \\
\text { Glyphosate degradation }\end{array}$ & ++++ & ++++ & ++++ & + & - & - & - & - & - & - & - \\
\hline 7 & $\begin{array}{l}\text { Unidentified bacteria } \\
\text { Glyphosate degradation }\end{array}$ & ++++ & ++++ & +++ & - & - & - & - & - & - & - & - \\
\hline 8 & $\begin{array}{l}\text { Unidentified bacteria } \\
\text { Glyphosate degradation }\end{array}$ & ++++ & ++++ & ++++ & + & + & - & - & - & - & - & - \\
\hline 9 & $\begin{array}{l}\text { Arthrobacter sp. } \\
\text { AQ5-06 } \\
\text { (Kx946127) } \\
\text { Phenol degradation }\end{array}$ & - & - & - & - & - & - & - & - & - & - & - \\
\hline 10 & $\begin{array}{l}\text { Rhodococcus sp. } \\
\text { AQ5-07(1) } \\
\text { (Kx946128) } \\
\text { Phenol degradation }\end{array}$ & - & - & - & - & - & - & - & - & - & - & - \\
\hline
\end{tabular}

(- : no growth; + : <5 colonies; ++ : 5-10; +++ : >10 colonies; ++++: >20 colonies)

The optimum $\mathrm{pH}$ for both Alcaligenes sp. AQ5-02 was 6 and Pseudomonas sp. AQ5-04 ranged between 6 to $7(\mathrm{P}<0.05)$, while Serratia sp. AQ5-03 showed the optimum $\mathrm{pH}$ of 7 for copper bioremoval. In strong acidic solution, $\mathrm{H}^{+}$competes for active bioremoval site with copper ions, which impedes bioremoval of copper by microbial biomass. Meanwhile, in alkaline solution, hydrates formed by the hydrolysation of copper ions precipitate on the surface of biomass that can decrease the copper bioremoval activity (Luo et al., 2006). Besides, variation in bioremoval of copper by microbial biomass at different $\mathrm{pH}$ could be due to the difference in sensitivity of cell wall molecules of bacterial cell to $\mathrm{pH}$. For instance, at low $\mathrm{pH}$, cell wall ligands tightly bind with the hydronium ions, and restrict the approach of metal cations due to repulsive force. On the contrary, at higher $\mathrm{pH}$ values, more ligands like carboxyl, phosphate imidazole and amino group are exposed and carry negative charges with a subsequent attraction of metallic ions with positive charge (Pardo et al., 2003). Most living organisms have been found to remove heavy metals, including copper at low $\mathrm{pH}$, due to their physiological properties (Ok et al., 2007). Another study revealed that at high concentration of metal ions such as copper will result in low pH (van der Ent and Edraki, 2016; Hatar et al., 2013). 
The former Mamut Copper Mine located in Sabah (Malaysia) was the only copper mine in Malaysia. The mine generated a plenty of environment issues has been reported to have acidic pH (3.9 \pm 0.15$)$ (van der Ent and Edraki, 2016). Thus, these selected strains could be utilised in order to uptake metal from the environment. Though their optimum pH were 6 and 7 , they still could perform metal reduction activity at very low $\mathrm{pH}$. The results indicate that the selected phenol- degrading strains; Alcaligenes sp. AQ5-02, Serratia sp. strain AQ5-03 and Pseudomonas sp. strain AQ5-04 can be used as potential bioremediation agents for Cu removal from the environment as they are potent in reducing copper through specific mechanisms.

\section{Acknowledgments}

This work was supported by PUTRA-IPS 9486100 and 9572300. We also thank Universiti Putra Malaysia for providing a GRF scholarship to Miss Shakirah Abd Wahab Sha'arani.

\section{References}

Aksu, Z., G. Eğretli and T. Kutsal: A comparative study of copper (II) biosorption on Ca-alginate, agarose and immobilized $C$. vulgaris in a packed-bed column. Proc. Biochem., 33, 393-400 (1998).

Akinkunmi, W.A., A.A.S.A. Husaini, A. Zulkharnain, T.M. Guan and H.A. Roslan: Mechanism of biosorption of $\mathrm{Pb}$ (ii) and $\mathrm{Cu}$ (ii) ions using dead biomass of Fusarium equiseti strain UMAS and Penicillium citrinum strain UMAS B2. J. Biochem. Microbiol. Biotechnol., 4, 1-6 (2016).

Alireza, S.: Isolation and characterization of Pseudomonas resistant to heavy metals and poly aromatics hydrocarbons (PAHs) from Persian Gulf sediments. Afr. J. Biotechnol., 11, (2012). https:// doi.org/ 10.5897/AJB11.3450

Bajerski, F., D. Wagner and K. Mangelsdorf: Cell membrane fatty acid composition of Chryseobacterium frigidisoli PB4T, isolated from Antarctic glacier fore field soils, in response to changing temperature and $\mathrm{pH}$ conditions. Front. Microbiol., 8, (2017). https://doi.org/ 10.3389/ fmicb. 2017.00677

Busi, S., R. Chatterjee, J. Rajkumari and S. Hnamte: Ecofriendly biosorption of dyes and metals by bacterial biomass of Aeromonas hydrophila RC1. J. Environ. Biol., 37, 267-274 (2016).

Duraipandian, M., R. Sevugaperumal and V. Ramasubramanian: Assessment of copper caused stress in terms of morphometric, pigmental, biochemical and enzymatic characteristics of Vigna unguiculata (L). J. Adv. Botany Zool., 3, (2015). doi: 10.15297/ JABZ. V312.05

Ghosh, A. and P.D. Saha: Optimization of copper bioremediation by Stenotrophomonas maltophilia PD2. J. Environ. Chem. Engin., 1, 159-163 (2013).

Halmi, M.I.E., M.E. Khayat, B. Gunasekaran, N.A. Masdor and M.F.A. Rahman: Near real-time biomonitoring of copper from an industrial complex effluent discharge site using a plant protease inhibitive assay. Bioremediat. Sci. Tech.Res., 4, 10-13 (2016).

Hammaini, A., F. González, A. Ballester, M.L. Blázquez and J.A. Muñoz: Biosorption of heavy metals by activated sludge and their desorption characteristics. J. Environ. Manag., 84, 419-426 (2007).

Hansda, A., V. Kumar and Anshumali: Biosorption of copper by bacterial adsorbents: Areview. Res. J. Environ. Toxicol., 9, 45-58 (2015).

Hasayen, K.A., H. Al-Osaimi, A.M. Aljohany and H.M. AL-Jawdah: Spatial distribution of heavy metals in water, soil and anuran's livers from
Al-Hayr area - Riyadh, Saudi Arabia. J. Environ. Biol., 38, 231-236 (2017).

Hatar, H., S.A. Rahim, W.M. Razi and F.K. Sahrani: Heavy metals content in acid mine drainage at abandoned and active mining area. AIP Conference Proceedings., 1571,641-646 (2013).

Jaiswar, S., M.A. Kazi and S. Mehta: Bioaccumulation of heavy metals by freshwater algal species of Bhavnagar, Gujarat, India. J. Environ. Biol., 36, 1361-1366 (2015).

Karamba, K.I., S.A. Ahmad, A. Zulkharnain, M.A. Syed, K.A. Khalil, N.A Shamaan, F.A. Dahalan and M.Y. Shukor: Optimisation of biodegradation conditions for cyanide removal by Serratia marcescens strain AQ07 using one-factor-at-a-time technique and response surface methodology. Rendiconti Lincei., 27, 533-545 (2016).

Khayat, M.E., M.F.A. Rahman, M.S. Shukor, S.A. Ahmad, N.A. Shamaan and M.Y. Shukor: Characterization of a molybdenum-reducing Bacillus sp. strain khayat with the ability to grow on SDS and diesel. RendicontiLincei., 27, 547-556 (2016).

Lee, G.L.Y., S.A. Ahmad, N.A. Yasid, A. Zulkharnain, P. Convey, W.L.W. Johari, S.A. Alias, G. Gonzalez-Rocha and M.Y. Shukor: Biodegradation of phenol by cold-adapted bacteria from Antarctic soils. Polar Biol., 41, 553-562 (2018).

Luo, S., L. Yuan, L. Chai, X. Min, Y. Wang, Y. Fang and P. Wang: Biosorption behaviors of $\mathrm{Cu}^{2+}, \mathrm{Zn}^{2+}, \mathrm{Cd}^{2+}$ and mixture by waste activated sludge. Trans. Nonferrous Met. Soc. China., 16, 14311435(2006).

Majumder, S., G. Gangadhar, S. Raghuvanshi and S. Gupta: A comprehensive study on the behavior of a novel bacterial strain Acinetobacter guillouiae for bioremediation of divalent copper. Bioproc. Biosys. Engin., 38, 1749-1760 (2015).

Manogaran, M., M.Y. Shukor, N.A. Yasid, W.L.W. Johari and S.A. Ahmad: Isolation and characterisation of glyphosate-degrading bacteria isolated from local soils in Malaysia. Rendiconti Lincei, 28 471-479 (2017).

Nageswaran, N. and P.W. Ramteke: Antibiotic susceptibility and heavy metal tolerance pattern of Serratia marcescens isolated from soil and water. J. Bioremediat. Biodegradat., 3, (2012). https:// doi.org/ 10.4172/2155-6199.1000158

Ok, Y.S., J.E. Yang, Y.S. Zhang, S.J. Kim and D.Y. Chung: Heavy metal adsorption by a formulated zeolite-Portland cement mixture. J. Hazard. Mater., 147, 91-96 (2007).

Ölmezoğlu, E., B.K. Herand, M.S. Öncel, K. Tunç and M. Özkan: Copper bioremoval by novel bacterial isolates and their identification by 16S rRNA gene sequence analysis. Turk. J. Biol., 36, 469-476 (2012).

Oves, M., M.S. Khan and A. Zaidi: Biosorption of heavy metals by Bacillus thuringiensis strain OSM29 originating from industria effluent contaminated North Indian soil. Saudi J. Biol. Sci., 20, 121$129(2013)$

Pandiyan, S. and D. Mahendradas: Application of bacteria to remove $\mathrm{Ni}$ (II) ions from aqueous solution. European J. Sci. Res., 52, 345-358 (2011).

Pardo, R., M. Herguedas, E. Barrado and M. Vega: Biosorption of cadmium, copper, lead and zinc by inactive biomass of Pseudomonas putida. Anal. Bioanal. Chem., 376, 26-32 (2003).

Porcheron, G., A. Garénaux, J. Proulx, M. Sabri and C.M. Dozois: Iron, copper, zinc, and manganese transport and regulation in pathogenic Enterobacteria: Correlations between strains, site of infection and the relative importance of the different metal transport systems for virulence. Front. Cell. Infect. Microbiol., 3 (2013). https:// doi.org/ 10.3389/ fcimb.2013.00090

Rajendran, P., J. Muthukrishnan and P. Gunasekaran: Microbes in heavy metal remediation. Indian J. Experimen. Biol., 41, 935-944 (2003). 
Shawky, Z.S., M.R. Bahgt and M.T. Usama: Biosorption of copper and lead using bacterial biomass of Bacillus cereus and Bacillus subtilis isolated from El-Manzala Lake, Egypt. Inter. Adv. Res., 4, 263-274 (2016).

Tchounwou, P.B., C.G. Yedjou, A.K. Patlolla and D.J. Sutton: Heavy metal toxicity and the environment. In: Molecular, Clinical and Environmental Toxicology (Ed.: A. Luch). Basel: Springer Basel,
Vol. 101, pp. 133-164 (2012).

Van der Ent, A. and M. Edraki: Environmental geochemistry of the abandoned Mamut Copper Mine (Sabah) Malaysia. Environ. Geochem. Hlth., 40, 189-207 (2016).

Waykar, B. and R. Petare: Studies on monitoring the heavy metal contents in water, sediment and snail species in Latipada reservoir. J. Environ. Biol., 37, 585-589 (2016). 